\title{
Pharmaceutical Preparation of Kapardika Bhasma
}

\author{
Dr Santosh Pawale ${ }^{1}$, Dr. Suryawanshi Renuka ${ }^{2}$ \\ ${ }^{1}$ M.D.PhD. (Scholar) (Ayu.) Assisstant Professor, Post Graduate Department of Rasashatra \& B.K.,PMT’s Ayurved College, Shevgaon, \\ Ahmednagar, Maharashtra, India \\ ${ }^{2}$ M.D.PhD. (Scholar) (Ayu.) Assisstant Professor, Post Graduate Department of Rasashastra \& B.K., PMT's Ayurved College, Shevgaon, \\ Ahmednagar, Maharashtra, India
}

\begin{abstract}
Introduction: Rasashastra is a science of Ayurvedic pharmaceutics which deals with the drugs of mineral origin, their varieties, characteristics, processing techniques, properties and therapeutic uses. The Shodhana and Marana are two basic concepts of Rasashastra. Almost all drugs are advised to be processed with specific Shodhana and Marana methods before their internal uses, to remove their harmful effects and to convert it into absorbable form. By the application of various Shodhana and Marana processes prescribed in Rasa classics various physical and chemical changes takes place in the purified drug, which will be analyzed by applying some modern analytical test parameters. Materials and methods: In the present study Kapardika was purified and incinerated with reference mentioned in Rasatarangini and observations were documented. Results: Organoleptic characters didn't show any variation in three puta and heating pattern also similar. Discussion and conclusion: Kapardika shodhana and Marana was done by following the method prescribed in Rasatarangini and observations during Shodhana and Puta and after Shodhana and Puta were documented. A detailed work is discussed in article. After three puta Kapardika bhasma passed all bhasmapariksha.
\end{abstract}

Keywords: Shodhana, Marana, pharmaceutical study, Kapardika etc.

\section{Introduction}

Ayurveda is a holistic life science. It covers all aspects of human life. The subject matter of Ayurveda is experienced based and practical.

Rasaoushadhis have unique place in Ayurvedic therapeutics because of their qualities like Alpamatropayogitvat (used in less dose), Arucher-aprasangata (no incidence of bad taste) and Kshipramarogayadayitvat [1] (fast acting).

Drug manufacturing part of Ayurveda is dealt in Rasashastra. Rasashastra is a branch which deals with pharmaceutical technology in which process like shodhana, marana was carried out. Marana is most important pharmaceutical process applicable to the drugs of mineral origin for their conversion into ash form. As it is considered suitable for absorption and assimilation into the body. The process of making the metals into a fine powder by applying required quantity of heat is known as marana. [2]

Kapardika was subjected toShodhana and Maranaas per Rasatarangini . .Whitecolored Kapardikabhasma was obtained after three Gajaputa (classical heating system with 1000cowdungcakes) which passed all the classical bhasma parikshas i.e. Rekhapurnata (the bhasma should enter the furrows of finger), Varitara (the bhasmashould float on the still water surface), Nirdhuma (the prepared bhasma should not emit any fumes when exposed to fire), Niswadu (the bhasma should not possess any taste), Dantagrakachakachabhav ( bhasma when kept on tongue it will not produce kachakacha sensation ) [3].

\section{Materials and Methods}

Raw Kapardika which was procured from S.G. Phytopharma pharmacy, Kolhapur

\section{Associated drugs}

Kumari and Nimbu. Kumari was taken from herbal garden of PMT's Ayurved College, Shevgaon and Nimbu from local market. Fresh Nimbu swarasa was used for Kapardika shodhana and fresh Kumari swarasa was used for Kapardika marana.

\section{Equipments}

Dolayantra was used for Kapardika shodhana,Khalva yantra (Mortar and Pestle) was used for levigation during Chakrika (Pellet) formation, Gajputa was used for Kapardika bhasmanirmana, and Digital pyrometer was used to record the temperature during puta.

\section{Pharmaceutical processing}

\section{Shodhana of Kapardika}

Kapardika shodhana was done with the reference from Rasa tarangini [4] (12/89). Dolayantra was used for Kapardika shodhana. Dolayantra was filled with fresh Nimbu swarasa and a potalli prepared with raw Kapardika was immersed in this swarasa.This Dolayantra was kept on medium flame for three hours. While Swedana process precaution should be taken that, pottali should not touch the bottom, but completely dipped in Nimbu swarasa. [5] After three hours Kapardika was taken out and washed with hot water and observations were documented.

Table 1: Showing Organoleptic characters of Kapardika shodhana

\begin{tabular}{|c|c|c|}
\hline Features & Before shodhana & After shodhana \\
\hline Appearance & Solid, Heavy & Solid, Light weight \\
\hline Odour & No specific odour & No specific odour \\
\hline Colour & Yellow : Shiny & Light yellow, Less shining \\
\hline Taste & Kshariya & Amleeya \\
\hline Weight & 500 gms & 480 gms \\
\hline
\end{tabular}




\section{International Journal of Science and Research (IJSR) ISSN (Online): 2319-7064 \\ Index Copernicus Value (2015): 78.96 | Impact Factor (2015): 6.391}

\section{Kapardika Marana}

Kapardika marana was done with reference from Rasatarangini [6] (12/91-93) .Shuddha Kapardika was triturated with fresh Kumari Swarasa for 6 hours and when the mixture attained proper consistency, pellets were made and dried in the shade. They were then transferred to Sharava Samputa (sealed in earthen crucibles) and subjected to Gajaputa [7] using average 260 cowdung cakes. Total three puta were given to form Kapardika bhasma. For first puta highest temperature noted was $1020^{\circ} \mathrm{C}$ after 1 hour and the total duration of heat treatment was 6.5 hours (table 2). For second puta highest temperature was noted at $1087{ }^{\circ} \mathrm{C}$ after 1.15 hour and the total duration of heat treatment was 6.5 hours (table 3 ). For third puta highest temperature was noted at $1042{ }^{0} \mathrm{C}$ after 1.15 hour and the total duration of heat treatment was 6.15 hours (table $4)$.

Table 2: Showing temperatures and time of- 1st Gajputa.

\begin{tabular}{|c|c|c|}
\hline $\begin{array}{c}\text { Time } \\
\text { (min.) }\end{array}$ & $\begin{array}{c}\text { Temp. } \\
\text { in }^{0}\end{array}$ & Observation \\
\hline 0 & 25 & No fumes \\
\hline 15 & 63 & Fumes were appeared \\
\hline 30 & 189 & Very dense grayish white fumes, Flames appeared \\
\hline 45 & 522 & Flames increased, Fumes were decreased \\
\hline 60 & 1020 & Flames were stable, intermittent, fumes were absent \\
\hline 75 & 933 & Flames were decreased, red hot color inside pit \\
\hline 90 & 886 & Flames disappeared, Red hot color inside pit \\
\hline 105 & 873 & Pit was emptied $1 / 4$ from the upper margin \\
\hline 120 & 847 & Red hot colored pit, Sharava samputa was seen \\
\hline 135 & 846 & Sharava samputa were also became Red hot \\
\hline 150 & 782 & Color of the pit was became slight black \\
\hline 165 & 702 & Pit inside pit was became dark black \\
\hline 180 & 562 & Upper layer of Cow dung cakes were became grayish \\
& & black forming ash \\
\hline 195 & 455 & With upper grayish layer pit was $1 / 2$ parts emptied \\
\hline 210 & 325 & Grayish layer of ashes were on upside \\
\hline 225 & 266 & Sharavas were easily seen as the pit was $1 / 2$ emptied \\
\hline 240 & 200 & Beneath the sharavas there was fire without fumes \\
\hline 255 & 171 & Sharava was completely exposed as pit was $1 / 2$ \\
& & emptied \\
\hline 270 & 144 & Absence of flames, fumes, red hotness etc \\
\hline 285 & 117 & Absence of flames, fumes, red hotness etc \\
\hline 300 & 95 & Absence of flames, fumes, red hotness etc. \\
\hline 315 & 92 & Absence of flames, fumes, red hotness etc \\
\hline 330 & 89 & Absence of flames, fumes, red hotness etc. \\
\hline 345 & 80 & Absence of flames, fumes, red hotness etc \\
\hline 360 & 74 & Absence of flames, fumes, red hotness etc. \\
\hline 375 & 64 & Absence of flames, fumes, red hotness etc \\
\hline 390 & 51 & Absence of flames, fumes, red hotness etc. \\
\hline 405 & 30 & Sharavas\& pit were cooled, Sharava were taken out \\
\hline & & \\
\hline
\end{tabular}

Table 3: Showing temp. and Observation in $2^{\text {nd }}$ Gajputa

\begin{tabular}{|c|c|c|}
\hline $\begin{array}{c}\text { Time } \\
(\mathrm{min} .)\end{array}$ & $\begin{array}{c}\text { Temp. } \\
\text { in }{ }^{0} \mathrm{c}\end{array}$ & Observation \\
\hline 0 & 28 & No fumes \\
\hline 15 & 34 & Fumes were appeared \\
\hline 30 & 260 & Very dense grayish white fumes, Flames appeared \\
\hline 45 & 754 & Flames increased, Fumes were decreased \\
\hline 60 & 900 & Flames were stable, intermittent, fumes were absent \\
\hline 75 & 1087 & Flames were stable, intermittent, fumes were absent \\
\hline 90 & 1058 & Flames were stable, intermittent, fumes were absent \\
\hline 105 & 970 & Flames were decreased, red hot color inside pit \\
\hline 120 & 893 & Flames were disappear, red hot color inside pit \\
\hline 135 & 800 & Sharava samputa were also became Red hot \\
\hline 150 & 733 & Color of the pit was became slight black \\
\hline
\end{tabular}

\begin{tabular}{|c|c|c|}
\hline 165 & 644 & Pit inside pit was became dark black \\
\hline 180 & 593 & Pit inside pit was became dark black \\
\hline 195 & 513 & $\begin{array}{l}\text { Upper layer of Cow dung cakes were became } \\
\text { grayish black forming ash. }\end{array}$ \\
\hline 210 & 446 & With upper grayish layer pit was $1 / 2$ parts emptied \\
\hline 225 & 359 & Grayish layer of ashes were on upside \\
\hline 240 & 309 & Grayish layer of ashes were on upside \\
\hline 255 & 267 & $\begin{array}{c}\text { Sharava was completely exposed as pit was } 1 / 2 \\
\text { emptied }\end{array}$ \\
\hline 270 & 228 & Beneath the sharavas there was fire without fumes \\
\hline 285 & 198 & $\begin{array}{c}\text { Sharava was completely exposed as pit was } 1 / 2 \\
\text { emptied }\end{array}$ \\
\hline 300 & 160 & Absence of flames, fumes, red hotness \\
\hline 315 & 127 & Absence of flames, fumes, red hotness \\
\hline 330 & 102 & Absence of flames, fumes, red hotness \\
\hline 345 & 83 & Absence of flames, fumes, red hotness \\
\hline 360 & 63 & Absence of flames, fumes, red hotness \\
\hline 375 & 41 & Sharavas were cooled, pit was also cooled \\
\hline 390 & 25 & Sharava were cooled and taken out \\
\hline
\end{tabular}

Table 4: Showing temp and Observations in $3^{\text {rd }}$ Gajputa:-

\begin{tabular}{|c|c|c|}
\hline $\begin{array}{c}\text { Time } \\
(\mathrm{min} .)\end{array}$ & $\begin{array}{c}\text { Temp. } \\
\text { in }^{0} \text { c }\end{array}$ & Observations \\
\hline 0 & 26 & No fumes \\
\hline 15 & 45 & Fumes were appeared \\
\hline 30 & 200 & Very dense grayish white fumes, Flames appeared \\
\hline 45 & 613 & Flames increased, Fumes were decreased \\
\hline 60 & 975 & Flames were stable, intermittent, fumes were absent \\
\hline 75 & 1042 & Flames were stable, intermittent, fumes were absent \\
\hline 90 & 990 & Flames were stable, intermittent, fumes were absent \\
\hline 105 & 960 & Flames were decreased, red hot color inside pit \\
\hline 120 & 890 & Flames were disappear, red hot color inside pit \\
\hline 135 & 810 & Sharava samputa were also became Red hot \\
\hline 150 & 740 & Color of the pit was became slight black \\
\hline 165 & 672 & Pit inside pit was became dark black \\
\hline 180 & 600 & Pit inside pit was became dark black \\
\hline 195 & 592 & Upper layer of Cow dung cakes were became \\
& & grayish black forming ash. \\
\hline 210 & 465 & With upper grayish layer pit was $1 / 2$ parts emptied \\
\hline 225 & 372 & Grayish layer of ashes were on upside \\
\hline 240 & 290 & Grayish layer of ashes were on upside \\
\hline 255 & 525 & Sharava was completely exposed as pit was $1 / 2$ \\
& & emptied \\
\hline 270 & 212 & Beneath the sharavas there was fire without fumes \\
\hline 285 & 184 & Sharava was completely exposed as pit was $1 / 2$ \\
& & emptied \\
\hline 300 & 139 & Absence of flames, fumes, red hotness etc. \\
\hline 315 & 104 & Absence of flames, fumes, red hotness etc \\
\hline 330 & 186 & Absence of flames, fumes, red hotness etc. \\
\hline 345 & 62 & Absence of flames, fumes, red hotness etc \\
\hline 360 & 43 & Sharavas were cooled, pit was also cooled \\
\hline 375 & 26 & Sharava were cooled and taken out \\
\hline
\end{tabular}

Table 5: Showing results of Kapardika bhasma

\begin{tabular}{|c|l|l|l|l|l|l|}
\hline $\begin{array}{c}\text { Put } \\
\mathrm{a}\end{array}$ & Colour & $\begin{array}{c}\text { Lustur } \\
\mathrm{e}\end{array}$ & $\begin{array}{c}\text { Odou } \\
\mathrm{r}\end{array}$ & $\begin{array}{c}\text { Weigh } \\
\mathrm{t}\end{array}$ & $\begin{array}{l}\text { Touc } \\
\mathrm{h}\end{array}$ & Taste \\
\hline $1^{\text {st }}$ & $\begin{array}{l}\text { Light } \\
\text { yellowis } \\
\mathrm{h}\end{array}$ & Dull & Faint & $460 \mathrm{~g}$ & $\begin{array}{l}\text { Slight } \\
\text { soft }\end{array}$ & $\begin{array}{l}\text { Astringen } \\
\mathrm{t}\end{array}$ \\
\hline $2^{\text {nd }}$ & White & Dull & Faint & $450 \mathrm{~g}$ & $\begin{array}{l}\text { Soft } \\
\text { fine }\end{array}$ & $\begin{array}{l}\text { Slight } \\
\text { Astringen } \\
\mathrm{t}\end{array}$ \\
\hline $3^{\text {rd }}$ & White & Dull & Faint & $440 \mathrm{~g}$ & $\begin{array}{l}\text { Soft } \\
\text { fine }\end{array}$ & $\begin{array}{l}\text { Slight } \\
\text { Astringen } \\
\mathrm{t}\end{array}$ \\
\hline
\end{tabular}




\section{International Journal of Science and Research (IJSR) \\ ISSN (Online): 2319-7064}

Index Copernicus Value (2015): 78.96 | Impact Factor (2015): 6.391

\section{Bhasma pariksha:}

After $3^{\text {rd }}$ Puta Bhasma pariksha was done and bhasma shows Sookshmatva, Shlakshnatva, Varitaratva, Mrudutva, Rekhapurnatva, Dantagreakachikachitatva.

\section{Discussion}

Selection of raw material is the most important step in the pharmaceutics of Rasaushadhis. Authentic raw material with high quality assures of producing safe and efficacious finished product. In this regard, raw materials selected to prepare Kapardikabhasma were authenticated and procured from S.G. Phytopharma, Kolhapur. All the associated drugs like Kumari swarasa,Nimbu swarasa etc. which were used at various stages, were prepared under surveillance.

Kapardika shodhana was done according the specification mentioned in Rasatarangini. Here fresh Nimbu swarasa was used for shodhana process. Swedana by Dolayantra vidhi was applied for shodhana. Nimbu swarasa was taken in the quantity thatKapardika pottali should dip completely in it. While giving the heat level of Nimbu swarasa in dolayantra vessel should be maintained by adding fresh and warm Nimbu swarasa time to time. At the end of shodhana process $480 \mathrm{gms}$ of shuddha Kapardika was obtained. Here loss of $20 \mathrm{gms}$ was observed, it may be due to the impurities of raw Kapardika. The concept behind using Nimbu swarasa(acidic nature) as media may probably be to reduce hardness and particle size of the drug.

Kapardika marana also done with reference of Rasatarangini. During Marana, Shodhita Kapardika (480 g) was triturated withKumari swarasafor 6 hours and chacrika(pellets) prepared. Maranawas carried out by the classical puta method by adopting Gajaputa. Total of 760 cow dung cakes, each weighing average $100 \mathrm{~g}$ with $19 \mathrm{~cm}$ diameter and $2 \mathrm{~cm}$ thickness at the center were used.Total three puta were given for proper bhasma preparation. The \% loss observed after first puta was 4.16, after second puta 2.17 and that of third puta was $2.22 \%$. This loss in yield may be due to handling during preparation.

\section{Conclusion}

Shodhana by Swedana method using Dolayantra in Nimbu Swarasa and Marana by three Gajaputa are sufficient to obtain white colored Kapardika Bhasma which passed all bhasmapariksha.

\section{References}

[1] Shastri A. Rasa Ratna Sammuchaya of Vagbhata,ch.28,ver.1,9th edition 1995, Chaukhambha Amarbharati,Varanasi,p-570

[2] K.Nishteswar \& R.Vidyanath, Ayurvediya Rasashastra, cha.2,ver.18,Reprint 2010,Chaukhambha Surbharti,p-21

[3] D.A.Kulkarni, Commentator, Rasaratnasamucchaya of Vagbhata,cha.8, ver.26-30,Reprint 2007, Meharchand Lachhmandas, p-148

[4] Sharma S., Shastri K. Editor, Rasa Tarangini, Tarang 12, ver. 89, Reprint edition, New Delhi 1994, Motilal Banasasidas, P-300
[5] D.A.Kulkarni, Commentator, Rasaratnasamucchaya of Vagbhata,cha.9, ver.4,Reprint 2007, Meharchand Lachhmandas, p-162

[6] Sharma S., Shastri K. Editor, Rasa Tarangini, Tarang 12, ver. 91-93, Reprint edition, New Delhi 1994, Motilal Banasasidas, P-301

[7] D.A.Kulkarni, Commentator, Rasaratnasamucchaya of Vagbhata,cha.10, ver.53-54,Reprint 2007, Meharchand Lachhmandas, p-189 